\title{
РЕШЕНИЕ ВТОРОЙ ВСЕРОССИЙСКОЙ НАУЧНО-ПРАКТИЧЕСКОЙ ИНТЕРНЕТ-КОНФЕРЕНЦИИ С МЕЖДУНАРОДНЫМ УЧАСТИЕМ «СТРУКТУРА И ФИЗИКО-ХИМИЧЕСКИЕ СВОЙСТВА ЦЕЛЛЮЛОЗ
} И НАНОКОМПОЗИТОВ НА ИХ ОСНОВЕ»

Вторая Всероссийская научно-практическая Интернет-конференция с международным участием «СТРУКТУРА И ФИЗИКО-ХИМИЧЕСКИЕ СВОЙСТВА ЦЕЛЛЮЛОЗ И НАНОКОМПОЗИТОВ НА ИХ ОСНОВЕ» проходила в конференц-зале Интернет-портала http://cell.scilink.ru 6-7 октября 2016 г. Конференция проходила на технической базе кафедры физики твердого тела Петрозаводского государственного университета (ФГБОУ ВО ПетрГУ, г. Петрозаводск, Республика Карелия). В течение двух дней, 6 и 7 октября, велась активная дискуссия в режиме on-line.

В конференции приняли участие специалисты, аспиранты и студенты из вузов, научных центров, исследовательских институтов, в том числе академических, и предприятий. В числе 68 участников были представители ведущих российских университетов и научных организаций, в том числе Института высокомолекулярных соединений РАН (Санкт-Петербург), Института проблем химико-энергетических технологий СО РАН, Института химии Коми НЦ УрО РАН, Санкт-Петербургского государственного лесотехнического университета имени С.М. Кирова, Петрозаводского государственного университета, Северного Арктического федерального университета имени М.В. Ломоносова, Алтайского государственного университета, Сыктывкарского лесного института (филиал СПб гос. лесотехн. университета им. С.М. Кирова), и других организаций. В числе международных участников - исследователи из Белорусского государственного технологического университета (Минск, Белоруссия), Научно-исследовательского центра химии и физики полимеров (Ташкент, Узбекистан) и Израильской биотехнологической компании Designer Energy (Rehovot, Israel). Среди участников 10 докторов наук, 35 кандидатов наук и 15 аспирантов и магистров.

Было представлено 40 докладов, тематически разбитых на четыре секции. Тематика докладов была многообразной и охватывала 53 направления, которые были активно обсуждены в 203 сообщениях и вопросах. Наиболее многочисленной была Секция 1 «Структура, свойства и химическая модификация растительных полимеров» (24 доклада). Секция была наиболее посещаемой и доклады, представленные на ней, вызвали наибольший интерес и оживленную дискуссию. Второй и третьей по количеству обсуждаемых тем были Секция 2 «Строение и свойства новых функциональных и композиционных материалов на основе производных растительных полимеров» (12 докладов) и Секция 4 «Физико-химические основы технологии бумаги и картона, влияние исходного сырья на их структуру и свойства» (восемь докладов), которые, судя по количеству оставленных сообщений, вызвали одинаковый интерес участников. На Секции 3 «Технологии синтеза наноразмерных целлюлозных материалов из различных природных источников» было представлено всего три доклада, однако в будущем, надеемся, данное направление должно привлечь гораздо большее число заинтересованных участников конференции.

Следует отметить также, что наиболее активную дискуссию вызвал доклад Секции 1 «Рентгенография целлюлоз» автора Л.А. Алешиной из Петрозаводского государственного университета, а также доклад Секции 4 «О взаимосвязи поверхности растительных волокон и бумагообразующих свойств волокнистых полуфабрикатов» авторов И.В. Лебедева, Я.В. Казакова, Д.Г. Чухчина и К.А. Романенко из Северного (Арктического) федерального университета.

В целом конференция прошла на хорошем научном уровне, вызвала интерес участников, была живым и современным мероприятием. Она выявила ряд актуальных, но еще дискуссионных проблем, для ре- 
шения которых необходима активация сотрудничества различных ученых и исследовательских групп. Несомненным успехом явилось участие в конференции большого количества молодых исследователей, что вызывает надежду на дальнейшее развитие в России актуальной во всем мире тематики, посвященной исследованию природных полимеров.

По итогам работы конференции принято следующее решение.

Участники и Оргкомитет конференции признают актуальными направления научных исследований, представленные в докладах конференции «Структура и физико-химические свойства целлюлоз и нанокомпозитов на их основе».

Считать целесообразным проведение тематических конференций по проблемам физики и химии растительных полимеров один раз в три года в дистанционной форме. При подготовке и проведении очередной конференции в 2019 г. запланировать:

- более раннее оповещение докладчиков о технологии проведения обсуждения докладов в конференц-зале;

- организовать on-line-трансляции при открытии и закрытии конференции с использованием Skype, а также возможность использования Skype для общения между участниками конференции;

- рассмотреть возможность продления обсуждения докладов в конференц-зале на более длительный срок.

По итогам работы конференции Программный комитет произведет отбор докладов, вызвавших наибольший интерес, для публикации, а Организационный комитет сформирует и отредактирует Сборник трудов конференции в электронном виде. Окончательная редакция сборника будет проведена совместно с редакцией журнала «Химия растительного сырья» и зарегистрирована в РИНЦ, а содержание докладов размещено на сайте данного журнала.

Участники конференции выражают признательность кафедре физики твердого тела ПетрГУ и руководству ПетрГУ, обеспечившим подготовку, организацию и проведение Интернет-конференции на высоком научно-методическом и техническом уровнях и позволившим участникам из различных регионов России и стран принять участие в научных дискуссиях.

Оргкомитет конференции 